\title{
QUALITY STUDY OF FRUITS AND EXTRACTS FROM SIX ROMANIAN SEA BUCKTHORN VARIETIES
}

\author{
Carmen Mihaela Topală ${ }^{1, *}$, Ivona Cristina Mazilu ${ }^{2,3}$, Mădălina Vulpe ${ }^{1}$, Loredana Elena Vîjan ${ }^{1}$ \\ ${ }^{1}$ University of Piteşti, Faculty of Sciences, Physical Education and Computer Science, \\ Department of Natural Sciences, 1 Târgul din Vale Street, Piteşti, Argeş, RO 110142, Romania \\ ${ }^{2}$ University of Craiova, Horticulture Faculty, Doctoral School of Plant and Animal Resources Engineering, \\ 13 A.I. Cuza Street, Craiova, Dolj, RO 200396, Romania \\ ${ }^{3}$ Research Institute for Fruit Growing Pitesti, 402 Mărului Street, Piteşti, Argeş, RO 117450, Romania
}

\begin{abstract}
Sea buckthorn is currently used as a functional food, dietary supplements, and medicines raw material. Its fruits are a nutritional and therapeutical components valuable source (minerals, micro- and macronutrients, organic acids, amino acids, sugars, saturated, mono- and polyunsaturated fatty acids, vitamins, carotenoids, phenolic compounds). They are perishable because, having a thin epicarp and lacking the protective layer of wax, they easily dehydrate and lose their firmness as a result of postharvest metabolic processes. The study aims to determine how the very low temperature $\left(-18^{\circ} \mathrm{C}\right)$, establish for harvesting and long-term storage, affects the fruits quality in six varieties of sea buckthorn. Biometric (mass, size, color) and biochemical parameters ( $\mathrm{pH}$, titratable acidity, total soluble matter, sugar content, water content, dry matter, ash, phenolic compounds, flavonoids, tannins, carotenoids) were determined for this purpose. FTIR spectra for different types of extracts of sea buckthorn in the presence of ultrasonication or magnetic stirring were studied. The results indicated that the fruits stored at a temperature of $-18^{\circ} \mathrm{C}$ have retained their nutritional and therapeutic value, and can be consumed immediately after thawing or can serve as a raw material for further processing.
\end{abstract}

Keywords: biochemical constituents, frozen storage, FTIR, sea buckthorn fruits

\section{INTRODUCTION}

Society's concern for a health-promoting lifestyle has brought to consumers' attention the functional food concept, defined as that which, in its integral, fortified, enriched or potentiated form, offers benefits beyond the content of essential nutrients (such as minerals and vitamins) (Hasler, 2002). The plant world is an impressive resource of nutritional value components and biologically active ones. However, the association of so many biologically active components, in significant proportions and concentrations, as in the case of sea buckthorn fruits, is extremely rare.

Sea buckthorn, Hippophae rhamnoides L., is a shrub belonging to the Elaeagnaceae family, which is part of the spontaneous flora of Eurasia, and in Romania it is present in the sub-Carpathian areas of Moldova and Muntenia, in river valleys, Danube Delta and on the Black Sea coastal dunes. The shrub fruit (Hippophae rhamnoidesFructus) contains a complex of constituents: mineral elements micro and macronutrients, sugars (glucose, fructose, and xylose), organic acids (malic and succinic), amino acids (Sabir et al., 2005; Hussain et al., 2014; Sidor, 2015). They are vitamins 
(provitamin A, B, C, K, E), carotenoids (beta carotene, lycopene, lutein, zeaxanthin), flavonoids (isorhamnetin, quercitin, kaempferol, etc.) and essential fatty acids source (Pop et al., 2014; Stoian et al., 2017; Ursache et al., 2018). Unlike other species, sea buckthorn synthesizes and accumulates lipids in all morphological fruit parts (pulp, epicarp, and seed).

The lipid fraction consists of saturated fatty acids (13.7\%, predominating in the fruit pulp), unsaturated (86.3\% majority in seeds), and phytosterols (Li et al., 2007; Suryakumar and Gupta, 2011). The oil extracted from sea buckthorn seeds contains predominantly polyunsaturated and monounsaturated fatty acids (omega 3, 6, and 9: linolenic, linoleic and oleic acids), and fruit pulp oil contains mostly monounsaturated and saturated fatty acids: omega-7 (palmitoleic acid), its precursor, palmitic acid, as well as oleic acid (omega-9) (Yang and Kallio, 2001; Vescan et al., 2010).

The composition in unsaturated fatty acids and the unique ratio between omega 3 and 6 acids (1:1) (Suryakumar and Gupta, 2011) explains the protection, regeneration, and repair effects attributed to sea buckthorn fruits (Zielińska and Nowak, 2017). They have a particular flavor, pineapple-like, and acid - bitter taste, so few people appreciate them.

Since there are multiple benefits of raw fruit consumption, to extend their shelf life, modified atmosphere (medium-term) or storage at low temperature (long-term) are recommended. Furthermore, harvesting sea buckthorn fruits is a challenge, taking into account the fact that most varieties grown in Romania have branches that bear thorns, and the pedicel of the drupe is often short, complicating the process. To overcome this shortcoming, the harvest is performed by cutting the fruit branches and freezing them, followed by the vibration operation, which causes the pedicel to easily detach from the fruit branch.

The purpose of the present paper is the determination of some biometric and biochemical parameters, such as fruit mass, fruit size index, color, $\mathrm{pH}$, titratable acidity, total soluble substance, sugar content, dry matter, moisture, ash, polyphenols, flavonoids, tannins, carotenoids, in six sea buckthorn varieties from Romania area in conditions of keeping the fruit frozen, at $-18{ }^{\circ} \mathrm{C}$. Also, FTIR spectra for different types of extracts of sea buckthorn in the presence of ultrasonication or magnetic stirring were studied.

\section{MATERIALS AND METHODS \\ Plant material}

Sea buckthorn fruits at full maturity stages were manually harvested at the end of September 2019 at Research Institute for Fruit Growing Pitești Mărăcineni (44 $\left.544^{\prime} 08.43^{\prime \prime} \mathrm{N} ; 2^{\circ} 4^{\circ} 52^{\prime} 22.48^{\prime \prime} \mathrm{E}\right)$ and the Biocatina farm in Dâmbovița county $\left(44^{\circ} 44^{`} 39.61^{\prime \prime} \mathrm{N} ; 25^{\circ} 13^{\prime} 09.49^{\prime} \mathrm{E}\right)$. Two other varieties have been purchased from private growers from Constanța and Mureş counties, respectively. These cultivars were noted 'Piteşti 1' and 'Şerpeni' for the fruits harvested from Research Institute for Fruit Growing Pitesti Mărăcineni, 'DB1' and 'DB2' for the fruits harvested at the Biocatina farm in Dâmbovița, 'CT' and 'MS' for the fruits purchased from private growers from Constanța and Mureş. The fruits $(2 \mathrm{~kg} /$ cultivar) were randomly separated into 30-100 healthy fruits and $100 \mathrm{~g}$ samples, refrigerated, subsequently frozen and stored at a temperature of $-18{ }^{\circ} \mathrm{C}$ until the time of analysis (January 2020). Because no fresh fruits were analyzed, the aim was only to determine the limits for each biochemical compound analyzed, without attributing the results to a certain variety of sea buckthorn fruits. 


\section{Chemical substances}

Polyphenols (gallic acid), flavonoids (catechins), and Folin-Ciocalteu standards were purchased from Sigma Aldrich, Dako, Epp. Romania. Ethanol, acetone, hexane, sodium hydroxide, sodium carbonate, sodium nitrite, and aluminum chloride were purchased from Merck, Darmstadt, Germany.

\section{Chemical analysis and equipment}

To perform biometrical and biochemical analysis $100 \mathrm{~g}$ frozen fruits were defrosted at room temperature each time and immediately used in the methods requested. Each analysis was conducted in triplicate.

The mass of fruits was determined with an electronic balance with an accuracy of $0.01 \mathrm{~g}$, by weighing the samples (100 fruits) and calculating the average mass, expressed in $\mathrm{g} /$ fruit.

The fruit size index was determined by measuring the height, large and small diameter (the longitudinal and polar diameter) for each of the 100 fruits of a sample and calculating the volume of the fruit, based on the formula:

$$
V=\pi B^{2}: H^{2} / 6(2 H-B)
$$

where $B=\sqrt{(D} *$ d) (Jarcău, 2012).

The epicarp color parameters were measured with a Konika Minolta CR400 colorimeter; the samples consisted of 30 thawed fruits for each variety.

Soluble solids were determined using a Kruss DR201-95 refractometer and the results were reported as ${ }^{\circ}$ Brix at $20{ }^{\circ} \mathrm{C}$ (AOAC, 1999).

The moisture (water content) was determined gravimetrically, by drying $1 \mathrm{~g}$ Sea buckthorn fruit in

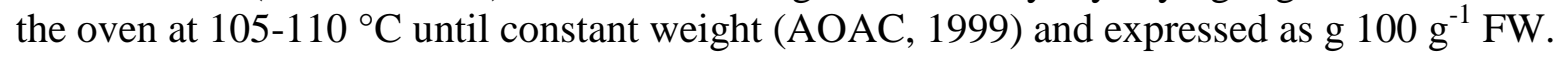

The ash content was determined by calcination of residue (resulted after extraction of water content) for 4 hours at $550{ }^{\circ} \mathrm{C}$. (AOAC, 1999) and expressed as $\mathrm{g} 100 \mathrm{~g}^{-1} \mathrm{DW}$.

The $\mathrm{pH}$ of fruit juice was measured by squeezing the sea buckthorn fruits, using a multimeter C561, calibrated with 7 and respectively $4 \mathrm{pH}$ solutions (AOAC, 1999).

The acidity was determined by titration of the fruits samples juice with a solution of $\mathrm{NaOH} 0.1 \mathrm{M}$ (AOAC, 1999), using the bromothymol blue (as an indicator); the results were expressed in $\mathrm{g}$ malic acid $100 \mathrm{~g}^{-1} \mathrm{FW}$.

The quantitative determination of polyphenols was performed by a spectrophotometric method using a UV-Vis spectrophotometer PerkinElmer Lambda25. The methodology proposed by Singleton and Rossi, 1965 was respected. The polyphenols content was expressed as mg gallic acid equivalent (GAE) $100 \mathrm{~g}^{-1} \mathrm{FW}$.

Quantification of flavonoids was performed by a spectrophotometric method using a UV-Vis spectrophotometer PerkinElmer Lambda25. The methodology proposed by Zhishen et al., 1999 was respected. Flavonoid concentration was estimated using the catechin calibration curve and, finally, their content was expressed as mg catechin equivalent (CE) $100 \mathrm{~g}^{-1} \mathrm{FW}$.

Quantitative determination of carotenoids (lycopene and $\beta$-carotene) was performed with a UV-Vis spectrophotometer PerkinElmer Lambda25, based on the methodology proposed by Zechmeister

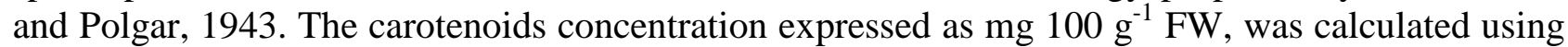
molar extinction coefficients of $184900 \mathrm{M}^{-1} \mathrm{~cm}^{-1}$ at $470 \mathrm{~nm}$ and $172000 \mathrm{M}^{-1} \mathrm{~cm}^{-1}$ at $503 \mathrm{~nm}$ for lycopene (DeRitter and Purcell, 1981; Rubio-Diaz et al., 2011), while $108427 \mathrm{M}^{-1} \mathrm{~cm}^{-1}$ at $470 \mathrm{~nm}$ and $24686 \mathrm{M}^{-1} \mathrm{~cm}^{-1}$ at $503 \mathrm{~nm}$ for $\beta$-carotene in hexane, respectively (Zechmeister and Polgar, 1943). 
The quantitative determination of tannins was performed by a spectrophotometric method using a UV-Vis spectrophotometer PerkinElmer Lambda25. The methodology proposed by Makkar et al., 1993 was respected. The tannins content was expressed as mg GAE $100 \mathrm{~g}^{-1} \mathrm{FW}$.

The study used a JASCO 6300 FTIR spectrometer in the $400-4000 \mathrm{~cm}^{-1}$ with a TGS detector, Cosine apodization function, SpectraManager II software. Spectra were taken at room temperature and were carried out by ATR (attenuated total reflection), using a diamond ATR crystal, with accumulation 100. The samples were measured in the diamond crystal, without the need for sample preparation in advance. Between measurements, the ATR crystal was cleaned with isopropyl alcohol. The instrument had a spectral resolution of $4 \mathrm{~cm}^{-1}$, which were used in all spectra determinations. So, the extracts of homogenised vegetal material with a concentration of $100 \mathrm{mg}$ $\mathrm{mL}$ were used. The mixture of hexane:ethanol:acetone in 2:1:1 volume ratio and pure hexane were used for extractions, under magnetic stirring and in ultrasonic bath, for 30 minutes.

\section{Statistic analysis}

Mean, standard deviation, and variation coefficient were calculated and minimum and maximum values were calculated using Microsoft Excel Descriptive Statistics.

\section{RESULTS AND DISCUSSIONS}

Consumers tend to anticipate the taste of fruits by relating their appearance to aspects, embodied in the size, the shape, and the color of the fruit skin. Therefore, appearance plays an important role in accepting and choosing fruit. The data regarding the analyzed biometric and biochemical parameters for studied sea buckthorn fruits are presented in table 1.

The studied fruits weigh varied between $0.22 \mathrm{~g}$ and $0.88 \mathrm{~g}$, while the mean value was $0.53 \pm 0.17 \mathrm{~g}$. The results are following Jarcău, 2012, and Jaiswal et al., 2017 studies who found a mean value of $22.75 \mathrm{~g}$ for 100 sea buckthorn fruits bought from a market in Fălticeni, Romania and, respectively values between $0.36 \mathrm{~g}$ and $0.91 \mathrm{~g}$ for Trans-Himalayan Seabuckthorn berries.

The berries height, large and small diameter was between $8.45-14.14 \mathrm{~mm}, 5.34-12.45 \mathrm{~mm}$ and $5.33-11.87 \mathrm{~mm}$, with mean values $11.56 \pm 1.34,8.83 \pm 1.51$ and $8.76 \pm 1.49$, respectively and their size index had a minimum value of $0.09 \mathrm{~cm}^{3}$ and a maximum of $0.93 \mathrm{~cm}^{3}$, while the mean value was $0.41 \pm 1.34 \mathrm{~cm}^{3}$, while other researchers (Jarcău, 2012, and Jaiswal et al., 2017) found $123.50-157.42 \mathrm{~mm}^{3}$ and $\mathrm{L}=6.5-7.5 \mathrm{~mm}, \mathrm{D}=4.74-6.28 \mathrm{~mm}$, respectively.

In analyzed sea buckthorn fruits, the dry matter and ash content were between $13.87-21.76 \%$ and $99.21-99.47 \%$, respectively. With a percentage of $78.24 \%$ ('CT' variety) $-86.13 \%$ ('MS' variety) water, sea buckthorn fruits have an important role in the hydration process of the human body. The amount of water contained in the fruits is important when it is intended to select varieties dedicated to obtaining juice or when the fruits are to be subjected to a dehydration process, whose efficiency is inversely proportional to their water content. In fruit, water is found in the extracellular environment (free water, which can be easily lost during the dehydration process), in the intracellular environment (in the cytoplasm and vacuoles, weakly bound water, $80-92 \%$ of the total amount of water) as well as in the cell wall area (water integrated into the cell wall structure represents $1-6 \%$ of the total amount of water and is called strongly bound water, not be easily lost in the dehydration process) (Khan et al., 2016; Khan and Karim, 2017). The amount of free water ranged for the tested varieties from 76.55 ('CT' variety) to 84.68 ('MS' variety), with a mean value of $81.05 \pm 3.39$. Our results are in agreement with the remarks from the two studies, in all the analyzed samples being obtained a free water level between $97.84 \%$ and $98.32 \%$. Similar values were presented by Jaiswal et al., 2017, which reported values between $84.53 \%$ and $87.34 \%$ for 
Current Trends in Natural Sciences

Vol. 9, Issue 17, pp. 273-283, 2020

https://doi.org/10.47068/ctns.2020.v9i17.034

Current Trends in Natural Sciences (on-line)

ISSN: 2284-953X

Current Trends in Natural Sciences (CD-Rom)

ISSN: 2284-9521

ISSN-L: 2284-9521

ISSN-L: $2284-9521$

moisture content in Trans-Himalayan Seabuckthorn berries and values between $73.6 \%$ and $85.3 \%$ in Indian cultivar.

Table 1. Biometric and biochemical quality indicators of the studied sea buckthorn fruits

\begin{tabular}{|c|c|c|c|c|}
\hline Measured parameter & Measure unit & Minim & Maxim & Mean \\
\hline Weigh & $\mathrm{G}$ & 0.22 ('CT') & 0.88 ('Piteşti 1') & $0.53 \pm 0.17$ \\
\hline Height (H) & $\mathrm{Mm}$ & 8.45 ('CT') & 14.14 ('Şerpeni') & $11.56 \pm 1.34$ \\
\hline Large diameter (D) & $\mathrm{Mm}$ & 5.34 ('CT') & 12.45 ('Piteşti 1') & $8.83 \pm 1.51$ \\
\hline Small diameter $(\mathrm{d})$ & $\mathrm{Mm}$ & 5.33 ('CT') & 11.87 ('DB1') & $8.76 \pm 1.49$ \\
\hline Size index & $\mathrm{cm}^{3}$ & 0.09 ('CT') & 0.93 ('Piteşti 1') & $0.41 \pm 0.17$ \\
\hline Total soluble solids (TSS) & ${ }^{\circ}$ Brix & 7.20 ('DB1') & 22.70 ('DB2') & $12.91 \pm 3.67$ \\
\hline Refraction index & & 1.3476 ('DB1') & 1.3641 ('DB2') & $1.3524 \pm 0.01$ \\
\hline pH & & 2.3 ('CT') & $3.0\left({ }^{\prime} \mathrm{DB} 1{ }^{\prime}\right)$ & $2.65 \pm 0.13$ \\
\hline TSS/pH & & 2.32 ('CT') & 8.41 ('DB2') & $4.87 \pm 1.37$ \\
\hline $\mathbf{L} *\left(\right.$ CIEL $\left.^{*} \mathbf{a} * \mathbf{b} *\right)$ & & 47.15 & 58.07 & $53.36 \pm 4.46$ \\
\hline $\mathbf{a} *\left(\right.$ CIEL $\left.^{*} \mathbf{a} * \mathbf{b} *\right)$ & & 20.10 & 35.42 & $27.00 \pm 5.24$ \\
\hline $\mathbf{b}^{*}\left(\mathbf{C I E L} \mathbf{a}^{*} \mathbf{b}^{*}\right)$ & & 24.74 & 35.43 & $31.14 \pm 4.33$ \\
\hline Free water & ${\mathrm{g} 100 \mathrm{~g}^{-1} \mathrm{FW}}$ & 76.55 ('CT') & 84.68 ('MS') & $81.05 \pm 3.39$ \\
\hline Moisture & ${\mathrm{g} 100 \mathrm{~g}^{-1} \mathrm{FW}}$ & 78.24 ('CT') & 86.13 ('MS') & $82.52 \pm 3.37$ \\
\hline Dry matter & ${\mathrm{g} 100 \mathrm{~g}^{-1} \mathrm{FW}}$ & 13.87 ('MS') & 21.76 ('CT') & $18.05 \pm 2.64$ \\
\hline Ash & g $100 \mathrm{~g}^{-1} \mathrm{DW}$ & 0.53 ('Piteşti 1') & 0.79 ('CT') & $0.59 \pm 0.09$ \\
\hline Acidity & g malic acid $100 \mathrm{~g}^{-1} \mathrm{FW}$ & 0.74 ('Şerpeni') & 1.91 ('Piteşti 1') & $1.31 \pm 0.46$ \\
\hline Phenolic compounds & mg GAE $100 \mathrm{~g}^{-1} \mathrm{FW}$ & 3960 ('Piteşti 1') & 8630 ('CT') & $5561 \pm 1690$ \\
\hline Tannins & mg GAE $100 \mathrm{~g}^{-1} \mathrm{FW}$ & 490 ('DB2') & 710 ('Şerpeni') & $573 \pm 83$ \\
\hline Flavonoids & mg CE $100 \mathrm{~g}^{-1} \mathrm{FW}$ & 340 ('DB2') & 486 ('CT') & $384 \pm 60$ \\
\hline \multirow[t]{2}{*}{ Carotenoids } & mg lycopene $100 \mathrm{~g}^{-1} \mathrm{FW}$ & 0.13 ('MS') & 1.77 ('Şerpeni') & $0.61 \pm 0.62$ \\
\hline & $\mathrm{mg} \beta$-carotene $100 \mathrm{~g}^{-1} \mathrm{FW}$ & 0.12 ('MS') & 2.08 ('Şerpeni') & $0.71 \pm 0.72$ \\
\hline
\end{tabular}

The total soluble content (TSS) varied between 7.20 ('DB1' variety) and 22.70 ('DB2' variety), with an average value of $12.91 \pm 3.67$. Similar values were presented by Kuhkheil et al., 2017, which reported values between 11.85 and 31.5 for TSS in sea buckthorn fruits in populations of central Alborz Mountains from Iran. This is also in agreement with previously reported data (7.4 12.6, Tiitinen et al., 2005; 10.15 - 14.80, Ercisli et al., 2007).

$\mathrm{pH}$ values of fruit juice varied from 2.3 ('CT' variety) to 3 ('DB1' variety), with an average $\mathrm{pH}$ of $2.65 \pm 0.13$. These values are in agreement with previously reported results for sea buckthorn juice in Finland (2.7 - 2.9, Tiitinen et al., 2005) and Turkey (2.63 - 2.98, Ercisli et al., 2007).

The minimum acidity, $0.74 \mathrm{~g}$ malic acid $100 \mathrm{~g}^{-1} \mathrm{FW}$, had the sea buckthorn fruits from 'Şerpeni' cultivar. The most acidic were the sea buckthorn fruits from 'Piteşti 1' cultivar (1.91 g malic acid $100 \mathrm{~g}^{-1} \mathrm{FW}$ ) and the mean value calculated was $1.31 \pm 0.46$.

The decisive role in the public's preferences is usually played by the food taste. A quality indicator used for this purpose is the ratio between the sugar content (expressed in degrees Brix) and the $\mathrm{pH}$ value of the fruit juice. Considering the sugar/pH ratio, it varied between 2.32 and 8.41 , with $4,87 \pm$ 
1,37 as the average value, the lowest value being obtained at the cultivar from Constanţa and the highest value being obtained at one of the two cultivars from Dâmbovița.

The color of an object can be described through the CIELab coordinate system. According to the CIE concept, the human eye has three types of color receptors: red, green, and blue, and all colors are combinations of these three colors. The CIEL*a*b* system considers two color coordinates, $a^{*}$, and $b^{*}$, as well as a brightness index, $\mathrm{L}^{*}$. The $\mathrm{a}^{*}$ parameter takes positive values for colors in the red range and negative values for those in the green range (from -127 , pure green, to 127 , pure red) while $\mathrm{b} *$ takes positive values for the yellow range and negative values for blue at -127 , pure blue, at 127 , pure yellow). $\mathrm{L}^{*}$ is an approximate measure of brightness (the property that each color can be considered the equivalent of a member on the grayscale, between white and black) (Granato and Mason, 2010). There are values between 0 (minimum brightness, when the color can be perceived as black) and 100 (for maximum color brightness). The color is given to the sea buckthorn fruits by the pigments they contain. Carotenoid pigments are responsible for the red-yellow coloration. Flavonoids, which function as co-pigment substances, are colorless or extremely pale yellow (Iwashina, 2015). The study color parameters had average values of $53.36 \pm 4.46$, for brightness, $27.00 \pm 5.24$ on the green-red scale, and $31.14 \pm 4.33$ on the yellow-blue scale, respectively.

Antioxidants in fruits and vegetables have defensive effects and are three main groups: vitamins, polyphenols, and carotenoids (Thaipong et al., 2006).

Polyphenols, secondary plant metabolites, are the most abundant antioxidants in human diets. Their consumption may reduce the risk of chronic degenerative diseases and the body's response to pathologic conditions (Nemzer et al., 2011). In analyzed sea buckthorn fruits, the amounts of polyphenols between $3960 \mathrm{mg}$ GAE $100 \mathrm{~g}^{-1} \mathrm{FW}$ ('Piteşti' variety) and $8630 \mathrm{mg} \mathrm{GAE} 100 \mathrm{~g}^{-1} \mathrm{FW}$ ('CT' variety) were found. As can be seen, the significant differences in the polyphenols content from the analyzed sea buckthorn fruits were found. Ercisli et al., 2007 reported values between $2131 \mathrm{mg}$ GAE $100 \mathrm{~g}^{-1} \mathrm{FW}$ and $5538 \mathrm{mg}$ GAE $100 \mathrm{~g}^{-1} \mathrm{FW}$ for ten sea buckthorn genotypes in Turkey. Similar results were obtained also by Kuhkheil et al., 2017, who reported a polyphenols content ranged between $2078 \mathrm{mg}$ GAE $100 \mathrm{~g}^{-1} \mathrm{FW}$ and $3460 \mathrm{mg}^{\mathrm{GAE}} 100 \mathrm{~g}^{-1} \mathrm{FW}$ for various sea buckthorn fruits from the populations of central Alborz Mountains in Iran.

Flavonoids are found in higher amounts in the epicarp than in the fruit pulp and represent a remarkable group of metabolites, with a growing role, plant development, involved in their survival. In the human organism flavonoids have important effects such as antimicrobial, anti $\square$ inflammatory, antioxidant, antiviral, anti-allergic, anticancer, antiulcer, antidiabetic, antiplasmodial, antihypertensive, anticonvulsant and all reducing risks for severe human diseases (De Conti Lourenço et al., 2013). They are also responsible for fruits astringent taste, together with tannins. In analyzed sea buckthorn fruits, the flavonoids content ranged from $340 \mathrm{mg} \mathrm{CE} 100 \mathrm{~g}^{-1} \mathrm{FW}$ ('DB2' variety) to $486 \mathrm{mg} \mathrm{CE} 100 \mathrm{~g}^{-1} \mathrm{FW}$ (' $\mathrm{CT}$ ' variety), our results being in agreement with those of Yuzhen and Fuheng, 1997; Bal et al., 2011; Kuhkheil et al., 2017.

Tannins, predominantly quantitative in the epicarp, were initially considered natural non-nutrients (due to their ability to bind proteins), but are now considered to play an important role in human health (Hussain et al., 2019). Also, proanthocyanidins have potential benefits if used topically for the protection of UV skin damage (Van Wijk et al., 2010). In analyzed sea buckthorn fruits, the

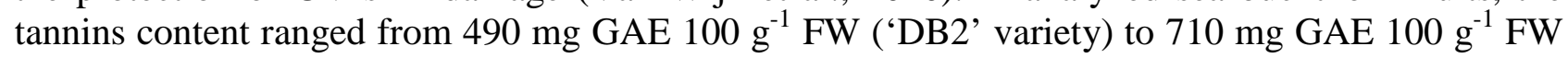
('Şerpeni' variety), these significant differences being determined by the agro-biological characteristics of analyzed cultivars. Similar values were presented by Kuhkheil et al., 2017, which 


\section{Current Trends in Natural Sciences}

Vol. 9, Issue 17, pp. 273-283, 2020

https://doi.org/10.47068/ctns.2020.v9i17.034

Current Trends in Natural Sciences (on-line)

ISSN: 2284-953X

Current Trends in Natural Sciences (CD-Rom)

ISSN: 2284-9521

ISSN-L: 2284-9521

ISSN-L: 2284-9521

reported values between $199 \mathrm{mg}$ GAE $100 \mathrm{~g}^{-1} \mathrm{FW}$ and $574 \mathrm{mg}$ GAE $100 \mathrm{~g}^{-1} \mathrm{FW}$ for extractable tannins from the sea buckthorn fruits in the populations of central Alborz Mountains in Iran.

Carotenoids are tetraterpenes that participate in the process of photosynthesis and that protect plants against photooxidative stress (Demmig-Adams and Adams, 2002). In the human body can play the role of provitamin A ( $\beta$-carotene), are involved in intercellular communication (Stahl et al., 2002), have antioxidant activity (Edge and Truscott, 2018) and shown beneficial effects on the reduction of cardiovascular diseases (Escobedo-Avellaneda et al., 2014). They protect from several degenerative conditions including cardiovascular diseases, cancer, immunity, and macular degeneration (Mayne 1996; Olson et al., 1999; Laos et al., 2007). Analyzing the UV-Vis absorption spectra of the sea buckthorn fruits supernatant, the content of lycopene and $\beta$-carotene was calculated. The lycopene content in the analyzed sea buckthorn ranged from $0.13 \mathrm{mg} 100 \mathrm{~g}^{-1} \mathrm{FW}$ in 'MS' variety to $1.77 \mathrm{mg}$

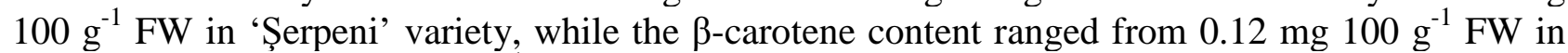
'MS' variety to $2.08 \mathrm{mg} 100 \mathrm{~g}^{-1} \mathrm{FW}$ in 'Şerpeni' variety. Similar results were obtained by Pop et al., 2014; Kuhkheil et al., 2017; Stoian et al., 2017 and Ursache et al., 2018 from various sea buckthorn varieties.

Figures 1 and 2 present the ATR-FTIR spectra for different types of extracts of sea buckthorn in the presence of ultrasonication or magnetic stirring.

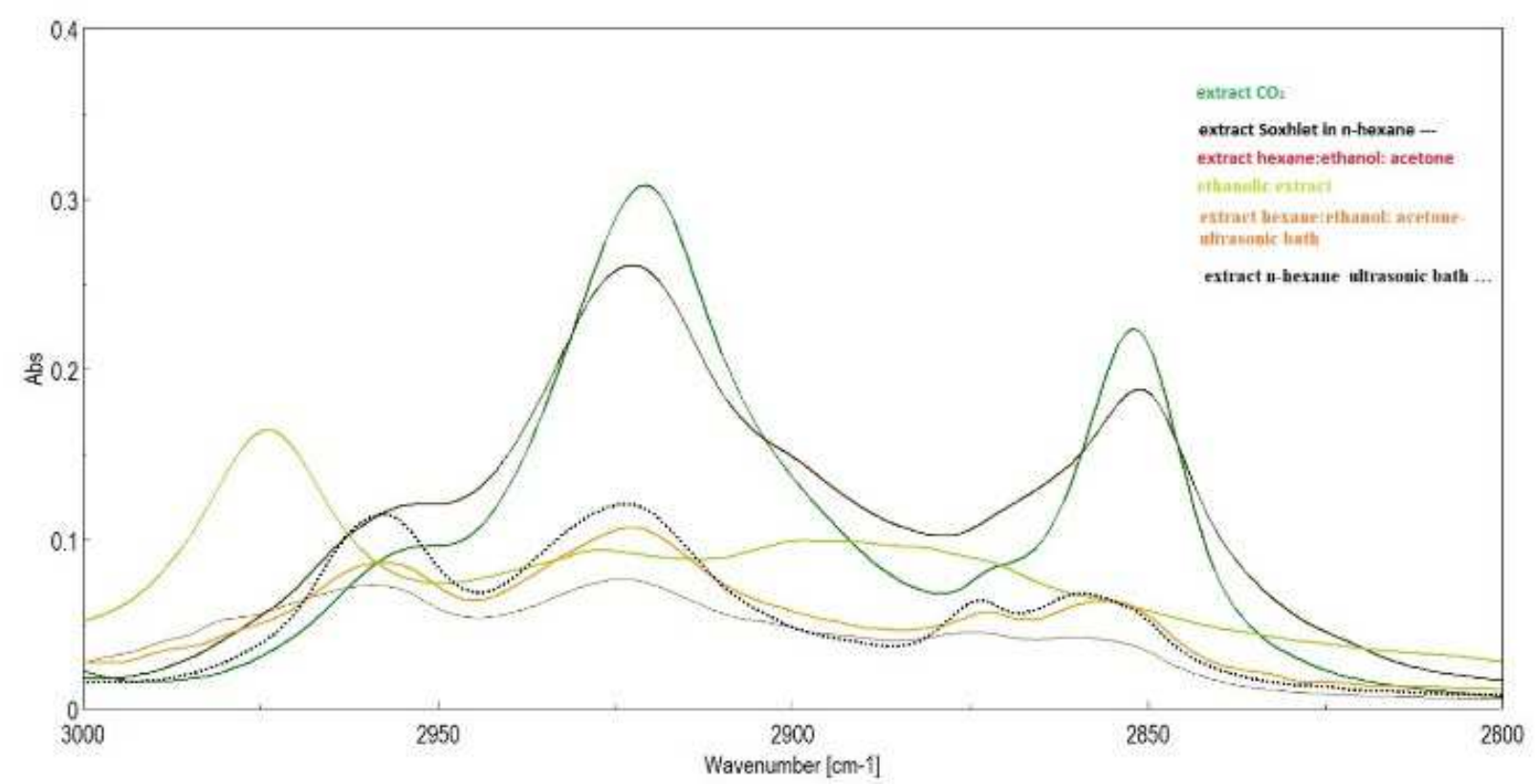

Figure 1. ATR-FTIR spectra of sea buckthorn extracts in region $3000-2800 \mathrm{~cm}^{-1}$

FTIR spectra of these sea buckthorn extracts present very similar spectral shapes due to the close chemical structure of fatty constituents.

The most significant bands from ATR-FTIR spectra of sea buckthorn extracts are shown in Table 2. In the IR spectra the most prominent vibrations observed in sea buckthorn extracts were the carbonyl group vibration, at approximately $1748 \mathrm{~cm}^{-1}$, a strong vibration for $\mathrm{C}=\mathrm{O}$.

Two intensive bands at $2850-2870 \mathrm{~cm}^{-1}$ and $2920-2923 \mathrm{~cm}^{-1}$ are assigned to the aliphatic $\mathrm{CH}_{2}$ asymmetric and symmetric stretching vibration. The bands at $1045-1077 \mathrm{~cm}^{-1}$ are assigned to the vibration of $\mathrm{C}-\mathrm{O}$ ester groups and $\mathrm{CH}_{2}$ groups. 


\section{Current Trends in Natural Sciences}

Vol. 9, Issue 17, pp. 273-283, 2020

https://doi.org/10.47068/ctns.2020.v9i17.034

Current Trends in Natural Sciences (on-line)

ISSN: 2284-953X

Current Trends in Natural Sciences (CD-Rom)

ISSN: 2284-9521

ISSN-L: 2284-9521

ISSN-L: 2284-9521

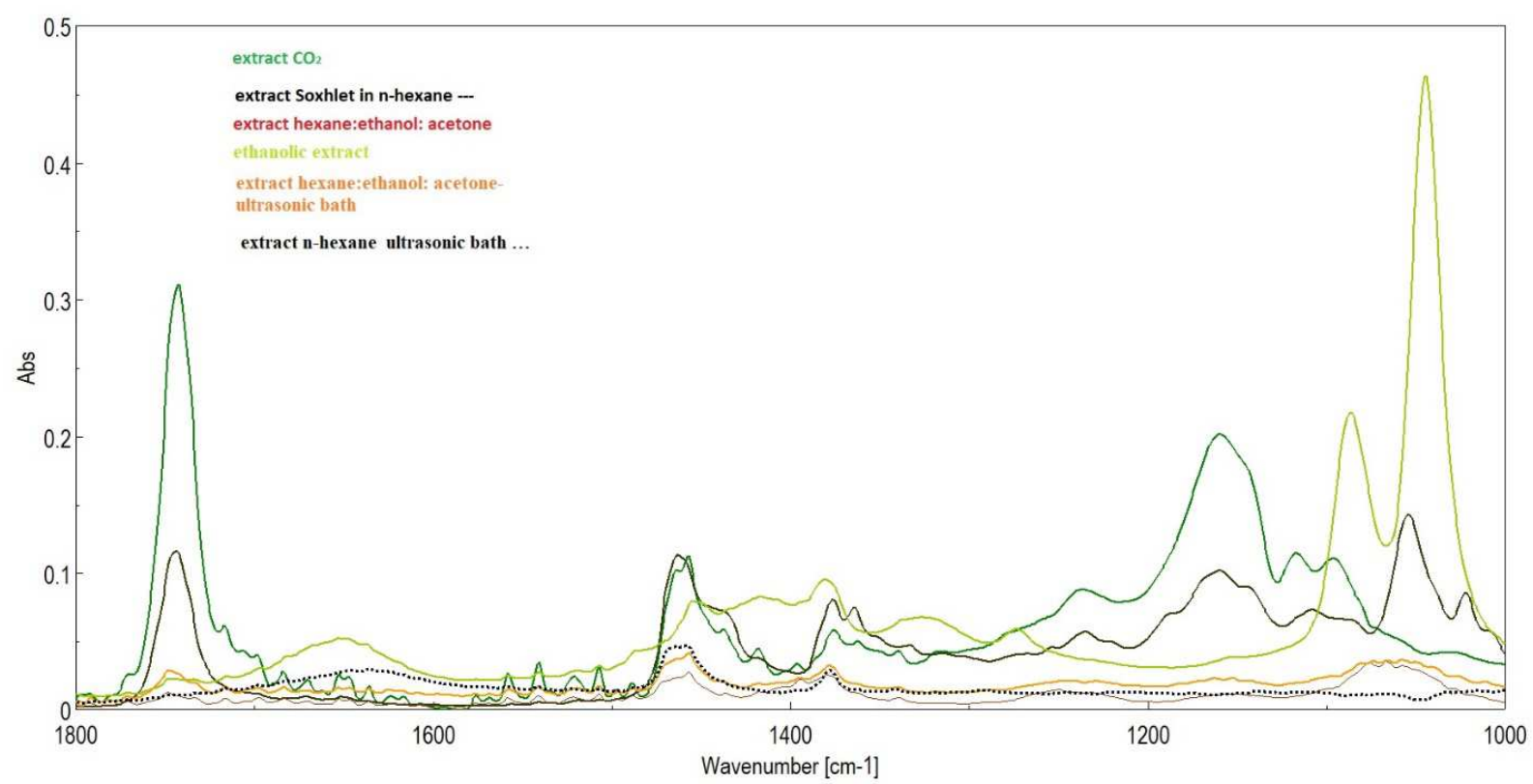

Figure 2. ATR-FTIR spectra of sea buckthorn extracts in region $1800-1000 \mathrm{~cm}^{-1}$

Table 2. Wavenumber $\left(\mathrm{cm}^{-1}\right)$ of selected bands in FTIR spectra of sea buckthorn extracts

\begin{tabular}{|l|c|c|c|c|}
\hline \multicolumn{1}{|c|}{ Oil//variety } & $v_{\mathrm{CH} 2 \text { asim }}\left(\mathrm{cm}^{-1}\right)$ & $v_{\mathrm{CH} 2 \text { sim }}\left(\mathrm{cm}^{-1}\right)$ & $v_{\mathrm{C}=\mathrm{O}}\left(\mathrm{cm}^{-1}\right)$ & $v_{\mathrm{C}-\mathrm{O} \text { asim }}\left(\mathrm{cm}^{-1}\right)$ \\
\hline Extract $\mathrm{CO}_{2}{ }^{-1}$ & 2920.66 & 2851.24 & 1742.37 & 1096.33 \\
\hline Extract Soxhlett* & 2922.59 & 2851.24 & 1744.3 & 1053.91 \\
\hline Extract 1.1 & 2923.56 & 2858.95 & 1748.16 & 1077.05 \\
\hline Extract 1.2 & 2922.59 & 2853.17 & 1747.19 & 1077.05 \\
\hline Extract 1.3 & $\mathbf{2 9 2 3 . 3 5}$ & $\mathbf{2 8 5 9 . 9 2}$ & $\mathbf{1 7 4 8 . 1 6}$ & $\mathbf{1 0 7 6 . 0 8}$ \\
\hline Extract 1.4 & 2923.56 & 2854.13 & 1748.16 & 1077.05 \\
\hline Extract 1.5 & 2923.56 & 2859.92 & 1748.16 & 1077.05 \\
\hline Extract 1.6 & 2924.52 & 2877.27 & 1748.16 & 1077.05 \\
\hline Extract 2.1 & 2925.48 & 2897.52 & 1756.26 & 1086.69 \\
\hline Extract 2.2 & 2924.52 & 2853.17 & 1743.33 & 1077.05 \\
\hline Extract 2.3 & $\mathbf{2 9 2 7 . 4 1}$ & $\mathbf{2 8 5 8 . 4 8}$ & $\mathbf{1 7 4 7 . 1 9}$ & $\mathbf{1 0 8 6 . 6 9}$ \\
\hline Extract 2.4 & 2924.52 & 2853.17 & 1743.33 & 1077.05 \\
\hline Extract 2.5 & 2925.48 & 2896.56 & 1747.19 & 1087.66 \\
\hline Extract 2.6 & 2923.56 & 2853.17 & 1742.37 & 1078.98 \\
\hline Extract 3.1 & 2929.34 & 2872.45 & 1717.3 & 1073.19 \\
\hline Extract 3.2 & 2920.91 & 2872.45 & 1716.34 & 1073.19 \\
\hline Extract 3.3 & $\mathbf{2 9 2 2 . 5 9}$ & $\mathbf{2 8 5 6 . 0 6}$ & $\mathbf{1 7 4 8 . 1 6}$ & $\mathbf{1 0 5 7 . 7 6}$ \\
\hline Extract 3.4 & 2920.66 & 2851.24 & 1741.41 & 1048.12 \\
\hline Extract 3.5 & 2927.41 & 2874.38 & 1732.73 & 1046.19 \\
\hline Extract 3.6 & 2925.48 & 2873.42 & 1732.73 & 1045.23 \\
\hline Extract 4.1 & 2924.52 & 2857.99 & 1747.19 & 1066.44 \\
\hline Extract 4.2 & 2923.56 & 2854.13 & 1747.19 & 1066.44 \\
\hline Extract 4.3 & $\mathbf{2 9 2 3 . 5 6}$ & $\mathbf{2 8 5 8 . 9 5}$ & $\mathbf{1 7 1 6 . 3 4}$ & $\mathbf{1 0 6 4 . 5 1}$ \\
\hline Extract 4.4 & 2923.56 & 2858.95 & 1716.34 & 1068.37 \\
\hline Extract 4.5 & 2923.56 & 2858.95 & 1716.34 & 1065.48 \\
\hline Extract 4.6 & 2923.56 & 2858.95 & 1716.34 & 1064.51 \\
\hline & & $* T$ & & \\
\hline
\end{tabular}

hexane:ethanol:acetone (1.1 - 1.6) and hexane (2.1 - 2.6) extract in magnetic stirring, hexane:ethanol:acetone (3.1 - 3.6) and hexane (4.1 - 4.6) extract in ultrasonic bath for different variety of sea buckthorn 


\section{CONCLUSIONS}

Six sea buckthorn varieties were evaluated in terms of some biometric and biochemical parameters, such as fruit mass, fruit size index, color, $\mathrm{pH}$, titratable acidity, total soluble substance, sugar content, dry matter, moisture and ash, polyphenols, flavonoids, tannins, carotenoids. There were significant differences in chemical composition from variety to variety. The variety with the highest refraction index, total sugar content, and $\mathrm{TSS} / \mathrm{pH}$ ratio was 'DB2' variety, presenting also the lowest polyphenols and tannins content. The ' $\mathrm{CT}$ ' variety had the highest dry matter, ash, polyphenols, and flavonoids content.

The quality indicators of the studied fruits fall within the limits mentioned regarding fresh fruits found in the literature, which proves that the temperature of $-18{ }^{\circ} \mathrm{C}$ preserves the organoleptic quality, the nutritional components and the biologically active ones so the sea buckthorn drupes of can be both be consumed and processed. However, the high variation between the analyzed samples of sea buckthorn shows the potential for selecting and breeding of the raw plant material for various defined purposes. Industrial cultivation, medicinal use, and processing of sea buckthorn berries need to be aligned according to different purposes, e.g., direct consumption, processing, juice production, extraction of active compounds, seed oil or pulp oil, etc. The medicinal components of berries will provide a very cheap raw material for national and international pharmaceutical industries, benefiting humanity worldwide.

Total Reflection Fourier Transform Mid-Infrared (ATR-FTIR) spectroscopy, a fast and costeffective tool requires minimal sample preparation, to investigate the response of leaf chemical composition.

In conclusion, we suggest that ATR-FTIR, as a rapid and low-cost approach, represents a reliable option to complement or replace more expensive and laborious biochemical analyses and it can be applied to the taxonomical discrimination of plant species.

\section{REFERENCES}

AOAC (1999). Food composition; additives; natural contaminants. Official Methods of Analysis of AOAC, 2. AOAC, Arlington.

Arif, S., Ahmed, S.D., Shah, A.H., Hassan, L., Awan, S.I., Hamid, A., Batool, F. (2010). Determination of optimum harvesting time for vitamin $\mathrm{C}$, oil and mineral elements in berries sea buckthorn (Hippophae rhamnoides). Pak $J$ Bot. 42(5), 3561-3568.

Bal, L.M., Meda, V., Naik, S.N., Satya, S. (2011). Sea buckthorn berries: A potential source of valuable nutrients for nutraceuticals and cosmoceuticals. Food Research International 44(7), 1718-1727.

Demmig-Adams, B., Adams, W.W. (2002). Antioxidants in photosynthesis and human nutrition. Science, 298(5601), 2149-2153.

De Conti Lourenço, R.M., da Silva Melo, P., de Almeida, A.B.A. (2013) Flavonoids as Antifungal Agents. (pp. 283-300) In: Razzaghi-Abyaneh, M., Rai, M. (eds) Antifungal Metabolites from Plants. Springer, Berlin, Heidelberg

DeRitter, E., Purcell, A.E. (1981). Carotenoid analytical methods. In: Bauernfeind JC (Eds). Carotenoids as colorants and Vitamin A precursors: technical and nutritional applications. Academic Press, New York, USA, pp 815-923.

Edge, R., Truscott, T.G. (2018). Singlet oxygen and free radical reactions of retinoids and carotenoids - a review. Antioxidants, 7(1), 5.

Ercisli, S., Orhan, E., Ozdemir, O., Sengul, M. (2007). The genotypic effects in the chemical composition and antioxidant activity of sea buckthorn (Hippophae rhamnoides L.) berries grown in Turkey. Sci Hort. 115(1), $27-$ 33.

Escobedo-Avellaneda, Z., Gutiérrez-Uribe, J., Valdez-Fragoso, A., Torres, J.A., Welti-Chanes, J. (2014). Phytochemicals and antioxidant activity of juice, flavedo, albedo, and comminuted orange. Journal of Functional Foods, 6, 470-481. 


\section{Current Trends in Natural Sciences}

Vol. 9, Issue 17, pp. 273-283, 2020

https://doi.org/10.47068/ctns.2020.v9i17.034

Current Trends in Natural Sciences (on-line)

ISSN: 2284-953X

Current Trends in Natural Sciences (CD-Rom)

ISSN: 2284-9521

ISSN-L: 2284-9521

ISSN-L: 2284-9521

Granato, D., Masson, M.L. (2010). Instrumental color and sensory acceptance of soy-based emulsions: a response surface approach. Food Science and Technology, 30(4), 1090-1096.

Hasler, C. M. (2002). Functional Foods: Benefits, Concerns, and Challenges - A Position Paper from the American Council on Science and Health. The Journal of nutrition, 132(12), 3772-3781.

Hussain, M., Ali, S., Awan, S., Hussain, M., Hussain, I. (2014). Analysis of minerals and vitamins in sea buckthorn (Hippophae rhamnoides) pulp collected from Ghizer and Skardu districts of Gilgit-Baltistan. Int. J. Biosci, 4 (12), 144-152.

Hussain, G., Huang, J., Rasul, A., Anwar, H., Imran, A., Maqbool, J., Razzaq, A., Aziz, N., Makhdoom, E.U.H., Konuk, M., Sun, T. (2019). Putative Roles of Plant-Derived Tannins in Neurodegenerative and Neuropsychiatry Disorders: An Updated Review. Molecules, 24(12), 2213-2230.

Iwashina, T. (2015). Contribution to Flower Colors of Flavonoids Including Anthocyanins: A Review. Natural product communications, 10(3), 529-544.

Jaiswal, S.G., Dole, B.R., Satpathy, S.K., Naik, S.N. (2017). Physical Attributes and Modelling of Trans-Himalayan Seabuckthorn Berries. Current Research in Nutrition and Food Science, 5(3), 391-397.

Jarcău, M. (2012). Some physical properties of seabuckthorn and how the packing conditions influence them. Food and Environment Safety Journal, XI(4), 103-107.

Khan, M.I.H., Wellard, R.M., Nagy, S.A., Joardder, M.U.H., Karim, M.A. (2016). Investigation of bound and free water in plant-based food material using NMR T2 relaxometry. Innovative Food Science and Emerging Technologies, 38, 252-261.

Khan, M.I.H., Karim, M.A. (2017). Cellular water distribution, transport, and its investigation methods for plant-based food material. Food Research International, 99, 1-14.

Kuhkheil, A., Naghdi Badi, H., Mehrafarin, A., Abdossi, V. (2017). Chemical constituents of sea buckthorn (Hippophae rhamnoides L.) fruit in populations of central Alborz Mountains in Iran. Research Journal of Pharmacognosy, 4(3), 1-12.

Laos, K., Lõugas, T., Mändmets, A., Vokk, R. (2007). Encapsulation of $\beta$-carotene from sea buckthorn (Hippophä rhamnoides L.) juice in furcellaran beads. Innovative Food Science \& Emerging technologies, 8(3), 395-398.

Li, T.S.C., Beveridge, T.H., Drover, J.C.G. (2007). Phytosterol content of sea buckthorn (Hippophae rhamnoides L.) seed oil: Extraction and identification. Food Chemistry, 101(4), 1633-1639.

Makkar, H.P.S., Blummel, M., Borowy, N.K., Becker, K. (1993). Gravimetric determination of tannins and their correlations with chemical and protein precipitation methods. Journal of the Science of Food and Agriculture 61(2), 161-165.

Mayne, S.T. (1996). Beta-carotene, carotenoids, and disease prevention in humans. FASEB J, 10(7), 690-701.

Nemzer, B.V., Rodriguez, L.C., Hammond, L., DiSilvestro, R., Hunter, J.M., Pietrzkowski, Z. (2011). Acute reduction of serum 8-iso-PGF2-alpha and advanced oxidation protein products in vivo by a polyphenol-rich beverage; a pilot clinical study with phytochemical and in vitro antioxidant characterization. Nutrition Journal, $10(1), 67$.

Olson, J.A., Shike, M., Shils, M.E. (1999). Modern nutrition in health and disease. Lippincott Williams \& Wilkins.

Pop, R.M., Weesepoel, Y., Socaciu, C., Pintea, A., Vincken, J.P., Gruppen, H. (2014). Carotenoid composition of berries and leaves from six Romanian sea buckthorn (Hippophae rhamnoides L.) varieties. Food Chemistry, 147, 1-9.

Raffo, A., Paoletti, F., Antonelli, M. (2004). Changes in sugar, organic acid, flavonol and carotenoid composition during ripening of berries of three seabuckthorn (Hippophae rhamnoides L.) cultivars. European Food Research and Technology, 219, 360-368.

Rubio-Diaz, D.E., Francis, D.M., Rodriguez-Saona, L.E. (2011). External calibration models for the measurement of tomato carotenoids by infrared spectroscopy. Journal of food composition and analysis, 24(1), 121-126.

Sabir, S.M., Maqsood, H., Hayat, I., Khan, M.Q., Khaliq, A. (2005). Elemental and nutritional analysis of sea buckthorn (Hippophae rhamnoides ssp. turkestanica) berries of Pakistani origin. Journal of medicinal food, 8(4), 518-522.

Shah, A.H., Ahmed, D., Sabir, M., Arif, S., Khaliq, I., Batool, F. (2007). Biochemical and nutritional evaluations of sea buckthorn (Hyppophae rhamnoides L. spp. Turkestanica) from different locations of Pakistan. Pak. J. Bot. 39(6), 2059-2065.

Sidor, A.M. (2015). The intake of minerals in the diet brought by the consumption of sea buckthorn (Hippophae rhamnoides L.) berries and juice. Food and Environment Safety, 14(3), 327-330.

Singleton, V.L., Rossi, J.A. (1965). Colorimetry of total phenolics with phosphomolybdic-phosphotungstic acid reagents. American Journal of Enology and Viticulture, 16(3), 144-158. 
Stahl, W., Ale-Agha, N., Polidori, M.C. (2002). Non-antioxidant properties of carotenoids. Biological chemistry, 383(34), 553-558.

Stoian, C., Livadariu, O., Turturică, M., Stanciuc, N., Mihalcea, L. (2017). Emerging technologies for mara sea buckthorn (Hippophae rhamnoides L.) berries valorification. Scientific Bulletin. Series F. Biotechnologies, XXI, $109-112$

Suryakumar, G., Gupta, A. (2011). Medicinal and therapeutic potential of Sea buckthorn (Hippophae rhamnoides L.). J. Ethnopharmacol., 138(2), 268-278.

Thaipong, K., Boonprakob, U., Crosby, K., Cisneros-Zevallos, L., Byrne, D.H. (2006). Comparison of ABTS, DPPH, FRAP, and ORAC assays for estimating antioxidant activity from Guava fruit extracts. Journal of Food Composition and Analysis, 19(6-7), 669-675.

Tiitinen, K.M., Hakala, M.A., Kallio, H.P. (2005). Quality components of sea buckthorn (Hippophae rhamnoides) varieties. J. Agric. Food Chem. 53, 1692-1699.

Topală, C.M., Ducu, C. (2014). Spectroscopic Study of Sea Buckthorn Extracts. Current Trends in Natural Sciences, $3(6), 48-54$.

Ursache, F.M., Andronoiu, D.G., Ghinea, I.O., Barbu, V., Ioniță, E., Cotârleț, M., Dumitrașcu, L., Botez, E., Râpeanu, G., Stănciuc, N. (2018). Valorizations of carotenoids from sea buckthorn extract by microencapsulation and formulation of value-added food products. Journal of Food Engineering, 219, 16-24.

Van Wijk, E.P., Van Wijk, R., Bosman, S. (2010). Using ultra-weak photon emission to determine the effect of oligomeric proanthocyanidins on oxidative stress of human skin. Journal of Photochemistry and Photobiology B: Biology, 98(3), 199-206.

Vescan, L.A., Pamfil, D., Bele, C., Matea, C., Sisea, C.R. (2010). Several lipophilic components of five elite genotypes of Romanian seabuckthorn (Hippophae rhamnoides subs. carpatica). Notulae Botanicae Horti Agrobotanici Cluj-Napoca, 38(2), 114-122.

Yang, B., Kallio, H.P. (2001). Fatty acid composition of lipids in sea buckthorn (Hippophae rhamnoides L.) berries of different origins. Journal of agricultural and food chemistry, 49(4), 1939-1947.

Yao, Y., Tigerstedt, P.M.A., Joy, P. (1992). Variation of vitamin C concentration and character correlation between and within natural Sea buckthorn (Hippophae rhamnoides L.) populations. Acta Agric Scand 42, 12-17.

Yao, Y., Tigerstedt, P.M.A. (1995). Geographic variation of growth rhythm, height and hardiness and their relations in Hippophae rhamnoides. J Am Soc Horticult Sci 120, 691-698.

Yuzhen, Z., Fuheng, W. (1997). Sea buckthorn flavonoids and their medicinal value. Hippophae, 10(1), 39-41.

Zechmeister, L., Polgar, A. (1943). cis-trans isomerization and spectral characteristics of carotenoids and some related compounds. Journal of the American Chemical Society 65(8), 1522-1528.

Zhishen, J., Mengcjheng, T., Jianming, W. (1999). The determination of flavonoid contents in mulberry and their scavenging effects on superoxide radicals. Food Chemistry 64(4), 555-559.

Zielińska, A., Nowak, I. (2017). Abundance of active ingredients in sea-buckthorn oil. Lipids in health and disease, 16(1), 95 . 